\title{
Kształtowanie się obrazu Gepidów w źródłach antycznych i wczesnośredniowiecznych (III-VII wieku)
}

\section{Wstęp}

Gepidowie są mało znanym ludem germańskim. W literaturze pojawiają się stosunkowo późno i zasadniczo nie występują jako główni bohaterowie opisywanych wydarzeń. Ich obecność i prezentacja w źródłach zmienia się i stopniowo wzbogaca o nowe elementy, dając w całości obraz dynamiczny i barwny, a jego analiza dostarcza informacji zarówno o samych Gepidach, jak i tworzy interesujący materiał porównawczy. Celem niniejszego artykułu jest wskazanie głównych elementów obrazu Gepidów w źródłach starożytnych i wczesnośredniowiecznych (III-VII wiek) oraz prześledzenie dynamiki przemian postrzegania, prezentacji i oceny tego plemienia ${ }^{2}$.

1 Dr hab. Tomasz Skibiński SAC, prof. UKSW, pracownik Katedry Historii Starożytnej Instytutu Historii na Wydziale Nauk Historycznych Uniwersytetu Kardynała Stefana Wyszyńskiego; e-mail: t.skibiński@uksw.edu.pl; ORCID: 0000-0001-5509-0865.

2 Także w opracowaniach Gepidowie są zaliczani do mniej istotnych bohaterów dziejów i są omawiani najczęściej wspólnie z innymi ludami o podobnym znaczeniu lub w mniejszych pracach. Na ich temat, zob. R. Steinacher, Rom und die Barbaren. Völker im Alpen - und Donauraum (300-600), Stuttgart 2017; W. Pohl, Die Gepiden und die Gentes an der Mittleren Donau, w: Die Völker an der mittleren und unteren Donau im fünften und sechsten Jahrhundert, red. H. Wolfram - F. Daim, Wien 1980, s. 240-272; W. Goffart, 


\section{Gens inhumana - diu invicta-ense furens Gepida}

Pierwsza grupa cech i postaw przypisywanych Gepidom jest związana z prowadzonymi przez nich walkami. Taka prezentacja jest obecna w miejszym lub większym stopniu we wszystkich źródłach do ich historii. Pierwsze informacje o Gepidach pochodzą z drugiej połowy III wieku, jednak do czasów potęgi Hunów pod wodzą Attyli w połowie $\mathrm{V}$ wieku, którym przez pewien czas byli podporządkowani, Gepidowie nie odgrywali szczególnie istotnej roli w historii i nie budzili większego zainteresowania historyków oraz myślicieli. Pojawiali się więc $\mathrm{w}$ źródłach sporadycznie, niekiedy w tle głównych wydarzeń i najczęściej pośród innych ludów.

Najstarszy tekst wspominający Gepidów to najprawdopodobniej Panegiryk Mamertyna wygłoszony w 291 roku na cześć Augusta Maksymiana współrządzącego Cesarstwem z Dioklecjanem³. Odmalowując odrodzenie Cesarstwa za ich rządów, panegirysta zwraca uwagę na wojny toczące się na terenach barbarzyńskich (a więc poza granicami Cesarstwa), a wśród skonfliktowanych ludów wymienienia Gepidów, których atakowali Goci i Tajfalowie ${ }^{4}$.

Kolejne przekazy zawarte są w źródle interesującym, ale kontrowersyjnym - Historia Augusta ${ }^{5}$. Zachowały się w niej dwa zapisy. W pierw-

Barbarian Tides. The Migration Age and the Later Roman Empire, Philadelphia 2006, s. 199-203; B. Magomedov, Gepids in the 3rd-5th centuries AD, „Ancient West \& East” 2/1 (2003) s. 146-156; M. Pandura, Origo Gepidarum, w: Origines mundi, gentium et civitatum, red. S. Rosik - P. Wiszewski, Wrocław 2001, s. 96-102; M. Pandura, ,Ardarici gladius”. Historia Królestwa Gepidów (454-567), „Slavia Antiqua” 45 (2004) s. 55-88.

3 Panegiryk wygłosił w Trewirze miejscowy retor Mamertyn z okazji pięciolecia rządów Maksymiana (Panegyricus III (11) 1, 1). Por. Panegirici Latini, ed. D. Lassandro - G. Micunco, Torino 2013, s. 96, przyp. 1 i 2.

4 Por. Panegyricus III (11) 17, 1.

5 Istotne są przede wszystkim nierozwiązane spory dotyczące datacji tego dzieła. Uznanie tekstu jako wczesnego źródła informacji o Gepidach opiera się na przyjęciu lat 325-337 jako zasadniczego czasu powstania zbioru. Obszerne omówienie argumentów za tą datacją: A. Lippold, Historia Augusta, w: RAC 15, 687-723 (zob. zwłaszcza k. 719, 
szym jest mowa o ataku na ziemie rzymskie podjętym przez „różne ludy Scytów”, w tym Gepidów ${ }^{6}$. Ten tekst, późniejszy z pewnością od poprzedniego, nawiązuje do wydarzeń z lat 268-269 i informuje, że wymienione ludy najechały tereny rzymskie wiedzione żądzą łupów (praede cupiditate) i dokonały wielu spustoszeń7.

Drugi tekst odnosi się do wydarzeń niewiele późniejszych, ale innego rodzaju. Dotyczy bowiem deportacji ludności barbarzyńskiej na tereny rzymskie w czasach cesarza Probusa (276-282). Informuje o przesiedleniu na tereny rzymskie 100 tys. Bastarnów, którzy dochowali cesarzowi wierności, a następnie mieszkańców innych szczepów, to jest Gepidów, Greutungów i Wandalów, co do których jednak stwierdza, że się zbuntowali i ,grasowali na lądzie i na okrętach niemal po całym świecie; niemało też szkody przynieśli sławie Rzymu"8. Deportacje barbarzyńców na teren Cesarstwa Rzymianie praktykowali od dawna i z powodzeniem, lecz w III wieku nabrały one nowej dynamiki ze względu na wyludnienie Cesarstwa i braki w szeregach armii spowodowane toczącymi się prawie nieustannie walkami oraz tzw. zarazą Cypriana ${ }^{9}$, która w drugiej połowie III wieku dziesiątkowała ludność państwa rzymskiego ${ }^{10}$. Szczegóły zapi-

721); J. Prostko-Prostyński, Adolf Lippold. Historia Augusta, Reallexikon für Antike und Christentum, 15, 1990, coll. 689-723, „Studia Źródłoznawcze” 36 (1997) s. 131-132.

6 Por. Historia Augusta. Claudius VI 2.

7 Informacje podane nieco dalej i sugerujące migracyjny charakter najazdów (por. Historia Augusta. Claudius VI 4-6) są uznawane za dodatek pochodzący od Trebeliusza Poliona mający na celu podkreślenie grozy sytuacji i wielkości najazdów. Nic nie wskazuje na to, żeby ataki wiązały się z migracyjnymi zamiarami Gepidów. Por. F. Paschoud, Commentaire de la Vita Claudii, w: Histoire Auguste, t. 4/3, ed. F. Paschoud, Paris 2011, s. 276-277.

8 Por. Historia Augusta. Probus XVIII 1-2, tł. H. Szelest, Warszawa 1966, s. 421. O osiedleniu Bastarnów, zob. także: Zosimus, Historia Nova I 71, 1.

9 To pandemia, pierwsza od czasów Marka Aureliusza, jaka wyniszczała Cesarstwo rzymskie ok. 249-262 roku, być może także z nawrotem ok. 270 roku. Więcej w: K. Harper, The Fate of Rome. Climate, Disease, and the End of an Empire, Princeton 2017, s. 136-145.

10 Por. A. Barbero, Barbari. Imigrati, profughi, importati nell'Impero romano, Bari 2006, s. 57-58. 
su budzą jednak wątpliwości, a udział Gepidów w tych wydarzeniach jest wątpliwy ${ }^{11}$.

Powyższe krótkie teksty pozwalają stwierdzić z całą pewnością, że Gepidowie na przełomie III i IV wieku funkcjonowali jako oddzielne plemię i - co ważne - tak byli postrzegani przez autorów rzymskich, o którym jednak autorzy nie mówią wiele (prawdopodobnie nie mając bliższych informacji). Gepidowie pojawiali się tu w kontekście ataków na Cesarstwo, walk między różnymi plemionami barbarzyńskimi albo jako plemię wchodzące w orbitę zainteresowań Rzymu w charakterze siły roboczej lub źródła rekrutów podczas deportacji na teren Cesarstwa.

Kolejna grupa tekstów dotyczy wydarzeń, jakie miały miejsce ponad wiek później. Do wydarzeń z początków V wieku, których uczestnikami byli Gepidowie, nawiązuje Hieronim ze Strydonu w liście do Geruchii napisanym w 409 roku. Gepidowie są wymienieni w kontekście spustoszeń Cesarstwa Rzymskiego w trakcie ataków licznych plemion na Galię na przełomie 406 i 407 roku, lecz w istocie to nie oni interesują autora - stawia on sobie za cel ukazanie przemijalności świata i odwiedzenie Geruchii od powtórnego małżeństwa poprzez podkreślenie niepewności świata i ciągłych zagrożeń ${ }^{12}$.

Dwa teksty pochodzące $\mathrm{z}$ połowy $\mathrm{V}$ wieku postrzegają i opisują Gepidów jako okrutnych. W latach czterdziestych Salwian - opisując niewiele wcześniejsze wydarzenia - stwierdził: „gens [...] Gipidarum inhumana"13, jednak i ten opis ma charakter instrumentalny, bo Salwian,

11 Inne źródła (Zosimus, Historia Nova I 71, 2; Panegyricus IV (8) 18, 3) mówią o buncie Franków (nie wspominając w ogóle o Gepidach). H. Wolfram (Storia dei Goti, Roma 1985, s. 106) akceptuje informacje Historia Augusta tylko w części dotyczącej Bastarnów, traktując wzmiankę o deportacji Gepidów, Greutungów i Wandalów jako typowy anachronizm dzieła. Odrzuca ją także F. Paschoud (Commentaire de la Vita Probi, w: Histoire Auguste, ed. F. Paschoud, t. 5/2, Paris 2002, s. 130). Są i głosy, że chodzi tu o jeńców pojmanych w regionach naddunajskich i na Bałkanach. Por. Barbero, Barbari, s. 252, przyp. 15.

12 Por. Hieronymus, Epistula 123, 15-16.

13 Por. Salvianus Massiliensis, De gubernatione Dei IV 14, 67. Gdzie indziej pisze także o ich ,nieludzkich obrzędach” (Gipidarum inhumanissimi ritus). Por. Salvianus Massiliensis, De gubernatione Dei IV 17, 82. 
zgodnie ze swoim zwyczajem, przechodzi natychmiast do moralizowania, a oskarżając Rzymian, zdejmuje winę z barbarzyńców. Gepidom przypisuje przy tym także skłonność do oszustwa, lecz uniewinnia ich, zauważając, że czynią to z nieświadomością winy ${ }^{14}$. Podobnie opisał ich Sydoniusz Apolinary. W panegiryku na cześć cesarza Awitusa wygłoszonym w nowy rok 456, referując zmasowany atak plemion barbarzyńskich pod wodzą Attyli na Galię w 451 roku, napisał: ,pugnacem Rugum [...] Gepida trux sequitur" ${ }^{15}$.

Zbieżność tych tekstów łączących Gepidów z okrucieństwem jest interesująca, nie można jednak nadawać jej zbyt wielkiego znaczenia, bo użyte $\mathrm{w}$ nich określenia związane semantycznie $\mathrm{z}$ okrucieństwem to typowy zestaw charakteryzujący barbarzyńców. Takie cechy, przypisywane tu Gepidom, pisarze późnego antyku nieuchronnie dostrzegali w barbarzyńskiej tożsamości, a podobne opisy dotyczyły wielu plemion ${ }^{16}$.

W 507 roku Ennodiusz z Pawii wygłosił panegiryk na cześć Teodoryka Wielkiego i nawiązał do jego starcia z Gepidami w czasie wędrówki Gotów z Bałkanów do Italii w 488 roku, w czasie której na ich drodze stanęli Gepidowie ${ }^{17}$. Goci znajdowali się w zdecydowanie gorszym położeniu niż Gepidowie, a panegirysta podkreśla ich wycieńczenie drogą i brakiem żywności ${ }^{18}$.

14 Por. Salvianus Massiliensis, De gubernatione Dei IV 17, 68.

15 Por. Sidonius Apollinaris, Carmen VII 321.

16 Por. R.W. Mathisen, Violent Behavior and the Construction of Barbarian Identity in Late Antiquity, w: Violence in Late Antiquity. Perceptions and Practices, ed. H.A. Drake, London - New York 2016, s. 28.

17 Opis nie pozwala ustalić, czy Gepidowie stanęli na drodze Teodoryka z własnej inicjatywy czy w porozumieniu z rządzącym w Italii Odoakrem. Por. Wolfram, Storia dei Goti, s. 486. Nie brak jednak głosów opowiadających się za którąś z hipotez. Por. Rota, Commento, s. 311. Trudno też wskazać jednoznacznie miejsce walki, jednak wspomniana w tekście Ulca fluvius jest identyfikowana najczęściej z rzeką Vuka (wówczas granicą Cesarstwa wschodniego), która wpada do Dunaju w mieście Vukovar. Por. Rota, Commento, s. 311-312.

18 Por. Ennodius, Panegyricus dictus clementissimo regi Theoderico VII 28; VII 31; VII 24. Teodoryk, póki znajdował się na terytorium Imperium wschodniego, 
W opisie zwraca uwagę kilka elementów. Pierwszym jest fakt, że Ennodiusz świadomie ogranicza się do opowiedzenia tylko tej jednej spośród wielu walk stoczonych przez Teodoryka ${ }^{19}$ i zauważa, że Gepidowie stanowili dla Gotów jedną z trzech poważnych przeszkód, obok zarazy i warunków naturalnych (rzeki) ${ }^{20}$. Gepidowie, chronieni przez rzekę, są też zaprezentowani jako lud od dawna niepokonany (gens diu invicta $)^{21}$. To charakterystyka ludów barbarzyńskich u Ennodiusza są to ludy dzielne i niepodbite, podczas gdy Teodoryka charakteryzują cechy właściwe dla Rzymian ${ }^{22}$. W ocenie tej pochlebnej opinii trzeba z pewnością wziąć pod uwagę prawa, jakimi rządził się panegiryk, wymagający, by wrogowie Teodoryka byli groźni. Wraz z wyborem właśnie tej spośród wielu walk stoczonych przez Teodoryka jest to opinia znacząca, bo reguły doboru materii do panegiryku wymagały także, by ukazać dokonania najbardziej chwalebne.

Dwa listy Teodoryka Wielkiego z 523 lub 524 roku przekazane w Variae Kasjodora ukazują grupę Gepidów będących już na służbie Teodoryka Wielkiego i dotyczą przemarszu ich oddziałów przez północną Italię do Galii, gdzie mieli wzmocnić siły ostrogockie przeciw Frankom. W pierwszym liście król wzywa sajona Werana do kontroli przemarszu dużej grupy Gepidow (multitudo Gepidarum) przez ziemie italskie, tak by żołnierze nie cierpieli biedy ani też nie doprowadzili do spustoszenia prowincji ${ }^{23}$. W drugim, kierowanym bezpośrednio do Gepidów, informuje, że rozkazał wydać im racje żywnościowe na drogę oraz że otrzymają

musiał korzystać tylko z zapasów żywności, jakie zabrał ze sobą. Por. Wolfram, Storia dei Goti, s. 486.

19 Zapowiada to zarówno we wstępie do opowieści, jak i w zakończeniu. Por. Ennodius, Panegyricus VII 28; VII 35; S. Rota, Commento, w: Magno Felice Ennodio, Panegirico del clementissimo re Teoderico (opusc. 1), ed. S. Rota, Roma 2002, s. 310.

20 Por. Ennodius, Panegyricus VII 29.

21 Por. Ennodius, Panegyricus VII 28.

22 W innym miejscu (por. Ennodius, Panegyricus V 19-22) Ennodiusz przedstawia podobnie Bułgarów (gens indomita). Por. Rota, Commento, s. 313.

23 Por. Cassiodorus Senator, Variae V 10. Teodoryk wyznacza dodatek do żołdu w wysokości trzech solidów tygodniowo, by Gepidowie mogli nabywać niezbędne pro- 
wspomniany także w liście do Werana dodatek do żołdu na konieczne zakupy w czasie drogi. Życząc szczęśliwej i spokojnej podróży, napomina, by przemarsz Gepidów był spokojny (ite moderati), a droga taka, jak przystoi pracującym dla wspólnego dobra ${ }^{24}$.

Obydwa pisma są istotną informacją o części plemienia Gepidów w okresie po ataku komesa Pitzii na Sirmium i świadectwem ich postrzegania przez Gotów. Jak się bowiem wydaje, w zachowanych w Variae dokumentach kancelarii królewskiej nie istnieje żaden analogiczny rozkaz kierowany do wojsk gockich, mimo że te na pewno uczestniczyły w licznych przemarszach. Znamienne jest, że król uważa za konieczne zapobiegać potencjalnym nadużyciom ze strony Gepidów, którzy, jak widać, postrzegani byli jako dziksi, bardziej niezdyscyplinowani i daleko mniej godni zaufania niż wojownicy ostrogoccy, poddani dyscyplinie gockiej organizacji wojskowej w Italii.

Z pierwszej połowy VI wieku pochodzi także świadectwo o innej grupie Gepidów pokonanych przez Pitzię. Jest to epitafium króla Gepidów Thrasaryka (syna króla Thraustyli poległego w 488 roku w bitwie pod Vukovar) z dawnego kościoła w Konstantynopolu, obecnie meczetu Vefa kilise camii w Stambule. Zrekonstruowana inskrypcja określa Thrasaryka jako comes domesticorum oraz króla Gepidów

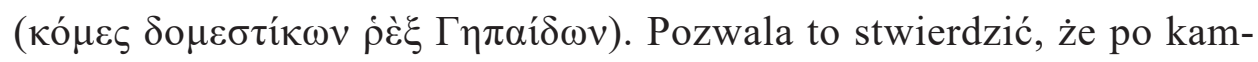
panii Pitzii uwieńczonej zdobyciem Sirmium król Thrasaryk został przyjęty przez dwór w Konstantynopolu i pozostawał na usługach cesarza, oraz że tam zmar225.

Rys obrazu Gepidów związany z ich walecznością nie ustaje także w późniejszych źródłach i pojawia się w wielu okolicznościach, lecz zostaje wzbogacony o nowe elementy, które przybliżają także technikę

dukty i powstrzymali się od rabunków, zobowiązując Werana do czuwania nad sprawiedliwością handlu.

24 Cassiodorus Senator, Variae V 11.

25 Por. H. Çentinkaya, An Epitaph of a Gepid King at Vefa Kilise Kamii in Istabul, REB 67 (2009) s. 225-229. 
walki Gepidów. Jordanes informuje, że Gepidowie należeli do bliskich sprzymierzeńców Hunów Attyli i po jego stronie walczyli na polach katalaunijskich ${ }^{26}$. Po śmierci Attyli poprowadzili jednak walkę o wyzwolenie spod panowania huńskiego. Zwycięska bitwa nad rzeką Nedao w 454 roku dała Gepidom własne państwo, które Jordanes nazywa nawet Gepidią $^{27}$. Opis bitwy pozostawiony przez Jordanesa jest bardzo dynamiczny ${ }^{28}$ i dostarcza informacji o uzbrojeniu i taktyce walki poszczególnych plemion. Jako domenę Gepidów Jordanes wskazuje miecz, pisząc „Gepida szaleje z mieczem w dłoni” ${ }^{29}$. Sam tekst to z pewnością krucha podstawa do wyciągania zbyt daleko idących wniosków co do techniki walki plemienia, lecz zauważana w opracowaniach ${ }^{30}$. W interpretacji passusu Jordanesa wzmacnia ją także dalsza informacja, że bitwę rozstrzygnął „miecz Ardaryka i sprzysiężonych”31.

Paradoksalnie okres królestwa Gepidów (454-567) jest stosunkowo słabo udokumentowany ${ }^{32}$, jednak w źródłach pojawiają się imiona ich

26 Por. Iordanes, Getica 199. Gepidowie byli łączeni z Hunami do tego stopnia, że w późniejszej historiografii Attyla był przedstawiany jako pochodzący z plemienia „Gepidów Hunów”. Por. Chronicon Paschale, t. 1, ed. L. Dindorf, CSHB, Bonn 1832, s. 587; Ioannes Malalas, Chronographia XIV 10. Tego typu pomyłki nie są jednak wyjątkiem w kronikach późnołacińskich i bizantyjskich (więcej przykładów zob. W. Goffart, Rome's Fall and After, London - Ronceverte 1989, s. 29). Por. Goffart, Barbarian Tides, s. 201 i 333-334.

27 Por. Iordanes, Getica 74. Na temat historii państwa Gepidów, zob. Pandura, Ardarici Gladius, s. 55-88.

28 Dziejopis nie troszczy się jednak o jednoznaczność przekazu. Wątpliwości dotyczą zarówno miejsca bitwy, jak i tego, kto po czyjej stronie brał w niej udział. Na temat różnych hipotez, zob. Pandura, Ardarici Gladius, s. 56-60.

29 Łac. ense furens Gepida. Por. Iordanes, Getia 261, tt. E. Zwolski, Jordanes, O pochodzeniu i czynach Gotów, w: Kasjodor i Jordanes. Historia gocka czyli scytyjska Europa, red. E. Zwolski, Lublin 1984, s. 136.

30 Por. M. Wilczyński, Exercitus barbarorum. Organizacja i działania wojsk ludów germańskich osiadlych $w$ Vi VI wieku w basenie Morza Śródziemnego, VoxP 63 (2015) s. 17; W. Pohl, Telling the Difference. Signs of Ethnic Identity, w: From Roman Provinces to Medieval Kingdoms, ed. T.F.X. Noble, New York 2006, s. 151, przyp. 45.

31 Łac. ardarici gladius conspiratorumque. Iordanes, Getica 262.

32 Por. Goffart, Barbarian Tides, s. 201. Pewną pomocą mogą służyć ustalenia archeologiczne. Zob. Z. Rácz - T. Vida, Germánok keletről és nyugatról: A gepidák és lan- 
królów albo opisy większych wydarzeń po linii powyższych charakterystyk. Królestwo przetrwało nieco ponad 110 lat. W bitwie pod Asfeld w 552 roku Gepidowie zostali pokonani przez Longobardów, a 15 lat później ostatecznie zniszczeni przez Longobardów sprzymierzonych z Awarami. Pamięć o nich przetrwała jednak w późniejszych źródłach, choć głównie we wspomnieniach dawnych wydarzeń i świetności.

\section{Ex Gothorum prosapie}

Nowe elementy obrazu Gepidów pojawiają się w połowie VI wieku i pochodzą od najważniejszych autorów dla poznania ich historii, jakimi są Jordanes $^{33}$ i Prokopiusz z Cezarei. Jordanes w barwnym opisie przedstawia etnogenezę Gepidów, przywołując ich pokrewieństwo z Gotami i przedstawiając legendę, która zawiera też ich charakterystykę. Przytacza opowieść o trzech statkach, którymi Goci przeprawili się pod wodzą legendarnego króla Beriga z pierwotnych siedzib w Skandii do Gothiskandzy. Jeden ze statków przybył do celu później od pozostałych (Jordanes nie widzi w tym żadnego szczególnego wydarzenia, stwierdzając, że taka sytuacja „nieraz się zdarza”) i przez to wydarzenie opóźniona navis została określona jako „gepanta”, Jordanes zaś wyjaśnia, że „w ich języku «leniwy» (pigra) brzmi gepanta” i informuje, że tak został nazwany lud, któremu dali początek pasażerowie statku, a z tego zniekształconego miana zrodziła się nazwa plemienia ${ }^{34}$.

gobardok régészete - Germanen von Osten und Westen: Die Archäologie der Gepiden und Langobarden, w: 7000 év története: Fejezetek Magyarország régészetéből - 7000 Jahre Geschichte: Einblicke in die Archäologie Ungarns, ed. O. Heinrich-Tamáska D. Winger, Remshalden 2018, s. 189-210; A.P. Kiss, Gepiden im heutigen Bulgarien?, „Studia Hungaro-Bulgarica III. Sumen-Szeged” (2014) s. 19-34.

33 Getica Jordanesa opiera się na Historii Gotów Kasjodora i to od tego historyka pochodzą przytoczone dalej informacje dotyczące etnogenezy i związanej z nią charakterystyki Gepidów. Por. Pandura, Origo Gepidarum, s. 96-97.

34 Por. Iordanes, Getica 95. Jordanes nie informuje, o jak długie opóźnienie chodziło, co daje możliwość różnych hipotez. E. Demougeot (La formation de l'Europe et les invasions Barbares. Des origines germaniques à l'avènement de Dioclétien, Paris 1969, 
Opis zawiera dwa istotne elementy: pokrewieństwo Gepidów z Gotami oraz powolność/gnuśność tych pierwszych ${ }^{35}$. Co do pierwszego z elementów należy zauważyć, że Jordanes przekazuje i podkreśla z pełnym przekonaniem, że Gepidowie bez wątpienia pochodzą z pokolenia Gotów (ex Gothorum prosapie) ${ }^{36}$ oraz dodaje, że się od swych pobratymców oddzielili, a ogarnięci zawiścią wybrali sobie odrębne siedziby ${ }^{37}$. Element pokrewieństwa jest też podkreślony, kiedy, opisując dzieje Gepidów w czasach Fastidy ${ }^{38}$, pierwszego poświadczonego w źródłach króla Gepidów, historyk informuje, że król ,,przykrym sporem podkopał prastary sojusz, oparty na więzach krwi” (consanguinitatis foedus), a król Ostrogota ze zgrozą patrzył na perspektywę walk między krewnymi (armis confligere cum propinquis), gdy Wizygoci przyjęli herezję ariańską i przekazali ją swym krewnym (parentibus suis) Ostrogotom i Gepidom, oraz gdy w czasie bitwy na polach katalaunijskich Ostrogoci i Gepidowie stawali przeciw swoim krewnym (parentes) Wizygotom ${ }^{39}$.

s. 363) sugeruje, że statek, który dał początek plemieniu Gepidów, przybył do celu przynajmniej wiek później niż dwa pierwsze.

35 Ta cecha Gepidów zostanie omówiona w następnym punkcie.

36 Iordanes, Getica 95 oraz 94 (,Gepidarum natio [...] arma in parentibus movit”).

37 Jordanes, Getica 95-96. Mariusz Pandura (Origo Gepidarum, s. 97-98) zauważa, że według relacji Jordanesa mityczne oddzielenie Gepidów od pozostałych plemion gockich dokonało się jeszcze na morzu przed przybyciem statków na wybrzeże, gdyż dwa dotarły tam wcześniej (można założyć, że podróżowały razem). Dwa statki gockie można też interpretować jako dwa plemiona - Wizygotów i Ostrogotów. W czasach, kiedy Kasjodor pisał swoją Historię Gotów a Jordanes - Getica, ten ostatni podział był już jasny. W mitycznych początkach opowiedzianej historii obydwie naves gockie podróżowały jeszcze razem, choć już rysował się początek odrębności.

38 Fastida według Jordanesa wszedł w konflikt z królem Ostrogotą, któremu podlegali Ostrogoci i Wizygoci, a konfrontacja zakończyła się przegraną przez Gepidów bitwą pod Galt. Por. Iordanes, Getica 97-100. Datacja tych wydarzeń jest kontrowersyjna. H. Wolfram (Storia dei Goti, s. 88, przyp. 12) datuje je na ok. 290 rok i łączy z walkami, o których mówi wspomniany wyżej Panegiryk na cześć Maksymiana (Panegyricus III (11) 17, 1). Nie brak jednak głosów, że to dwa oddzielne wydarzenia, a konflikt między Fastidą i Ostrogotą należy datować na 249 rok. Więcej w: Magomedov, Gepids, s. 149.

39 Por. Iordanes, Getica 97 (Fastida), 99 (Ostrogota), 133 (arianizm Wizygotów), 200 (bitwa na polach katalaunijskich). 
Tradycja gockiego pochodzenia Gepidów została podjęta także przez pisarzy bizantyjskich, którzy ją przekazali w różnych wersjach. Prokopiusz z Cezarei wyjaśniał:

We wcześniejszych czasach było wiele różnych ludów gockich, podobnie jak obecnie, jednak największymi i najsławniejszymi ze wszystkich są Goci, Wandalowie, Wizygoci oraz Gepidzi [...]. Wszyscy oni różnią się od siebie nazwą, jak powiedziano, ale niczym innym poza tym [...]. Wydaje mi się, że pierwotnie wszyscy należeli do jednego narodu a później zaczęli odróżniać się według imion poszczególnych wodzów ${ }^{40}$.

Walter Goffart w tym podkreślaniu pokrewieństwa ludów gockich dostrzega pewien złowieszczy rys, stwierdzając, że do 551 roku dwa z nich (Ostrogoci i Wandalowie) zostały już poskromione przez Justyniana, a trzeci (Wizygoci) balansował na granicy upadku ${ }^{41}$ - teza interesująca, choć możliwa do przyjęcia tylko z pewnymi zastrzeżeniami ${ }^{42}$. Podejmując

40 Procopius Caesariensis, De bellis III 2, 2-6, tł. D. Brodka, Prokopiusz z Cezarei, Historia Wojen, t. 1, Kraków 2013, s. 201-202. Ta idea podziału ludów gockich na Gotów (Ostrogotów), Wizygotów, Wandalów i Gepidów pochodzi prawdopodobnie od działającego na przełomie V i VI wieku Eustacjusza z Epifanei. Por. komentarz D. Brodki w: Prokopiusz z Cezarei, Historia Wojen, t. 1, s. 202. Więcej w: D. Brodka, Die Wanderung der Hunnen, Vandalen, West- und Ostgoten - Prokopios von Kaisereia und seine Quellen, „Millennium” 10 (2013) s. 13-38.

41 Por. W. Goffart, Barbarian Tides, s. 200-201 i 270, przyp. 57. Por. także: Procopius Caesariensis, De bellis VIII 24, 5, gdzie autor pisze, że cesarz Justynian nienawidził Gotów i zamierzał ich całkowicie wyprzeć z państwa rzymskiego.

42 Istotnie Wandalowie byli już wtedy skutecznie i ostatecznie zniszczeni, o bliskim końcu królestwa Ostrogotów można jednak wyrokować, przede wszystkim znając dalszy bieg wypadków, kiedy stało się jasne, jak skuteczna okazała się misja prowadzona przez Narsesa. H. Wolfram (Storia dei Goti, s. 613) ocenia, że latem 551 roku, po pierwszych klęskach Gotów i powrocie z Konstantynopola ich bezowocnego poselstwa, morale wojsk gockich osiągnęło najniższy poziom od 541 roku, jednak okres świetności Ostrogotów został zakończony ostatecznie dopiero w roku następnym klęską pod Busta Gallorum. Wizygotów z kolei - choć w tym okresie przeżywali trudności w czasie panowania Agili (549-554) - czekał jeszcze czas rozwoju, gdy nie tylko niweczyli cesarskie plany, ale i powiększali swe władztwo o tereny Swebów. 
ją, można jednak stwierdzić, że istotnie kres Gepidów był bliski. Wkrótce w imieniu Rzymian podjęli z nimi walkę Longobardowie ${ }^{43}$, co przybliżało koniec gepidzkiej wolności i istnienia ${ }^{44}$.

W XI wieku Gepidowie wzbogacili się o jeszcze jedną etymologię swej nazwy, ciągle po linii pokrewieństwa z Gotami, nawiązu-

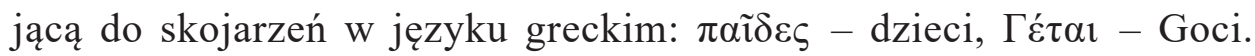

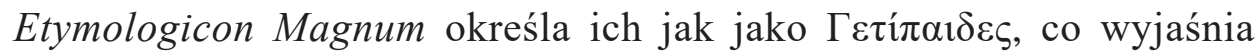

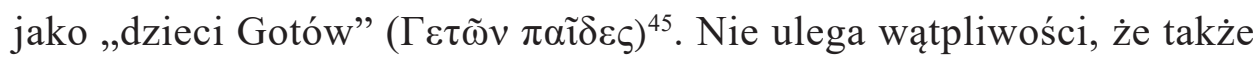
to określenie nawiązuje do idei rozpropagowanej przez Jordanesa, to jest do pokrewieństwa Gepidów z Gotami, która przyjęła się i zakorzeniła w historiografii.

Podsumowując tę część rozważań, należy zauważyć, że tradycja gockiego pochodzenia Gepidów została przekazana przez Jordanesa i Prokopiusza ok. 550 roku, a więc w okresie potęgi Gepidów, choć na niespełna dwa dziesięciolecia przed upadkiem ich państwa. Jest ona bardzo późna lecz pochodzi najprawdopodobniej z wcześniejszych dzieł Kasjodora i Eustacjusza. Dowodzi też przede wszystkim, że w czasach Jordanesa i Prokopiusza Goci oraz Gepidowie odczuwali wspólne pochodzenie i pokrewieństwo, ale w dużo mniejszym stopniu rzeczywistego pokrewieństwa dwóch plemion ${ }^{46}$.

43 Upadek Gepidów był bardzo mocno związany z działaniami cesarza Justyniana. $\mathrm{Na}$ temat polityki cesarza wobec Gepidów, por. A. Sarantis, War and Diplomacy in Pannonia and the Northwest Balkans during the Reign of Justinian. The Gepid Threat and Imperial Responses, DOP 63 (2009) s. 15-40. Na temat konfliktu longobardzko-gepidzkiego i jego znaczenia w polityce tego samego cesarza, por. P. Bystrický, Longobardsko-gepidské nepriatel'stvov case Justiniánovej vojny proti Gótom, „Byzantinoslovaca” 6 (2017) s. 31-47.

44 Por. Iordanes, Romana 386-487, gdzie jest zreferowana bitwa pod Aufeld (552 rok). Por. Goffart, Barbrian Tides, s. 200-201 i 333.

45 Etymologicon magnum seu magnum grammaticae penu 230.

46 Por. Goffart, Barbarian Tides, s. 199-200. 


\section{Pigri-pedestri}

Drugi element opisu Jordanesa, jak już zostało wspomniane, to charakterystyka ludu Gepidów, który otrzymał nazwę od spóźnionego stat$\mathrm{ku}$ - gepanta, czyli pigra (navis) ${ }^{47}$. Gepidowe przybyli nim na wybrzeże Gothiskandzy, a z tego zniekształconego określenia, jak informuje dziejopis, zrodziła się nazwa „Gepidowie”. Określenie pigra w tym kontekście możemy tłumaczyć jako 'powolny, gnuśny, leniwy, ociężały'48, więc te określenia mają charakteryzować lud Gepidów. Badania nie poświadczają podanej ludowej etymologii nazwy ${ }^{49}$, ale Jordanes nie tylko ją przytacza, ale podkreśla i uzasadnia, wyrażając przekonanie, że nie jest to wyjaśnienie błędne, ponieważ Gepidowie są opieszali z charakteru i ociężali $\mathrm{w}$ ruchach (tardioris ingenii et graviores corporum velocitate) $)^{50}$.

Ten sam motyw powraca niewiele dalej w opisie walki Gepidów z Gotami. Jordanes zauważa, że gdy doszło do walki, obie strony miały podobne uzbrojenie i stosowały podobną technikę bitewną (wywodzili się z jednego plemienia), lecz Goci wygrali dzięki lepszej sprawie i bystrości umysłu (causa melior vivacitasque ingenii) ${ }^{51}$, co jest oczywistym nawiązaniem do wspomnianej niewiele wcześniej „opieszałości charakteru" (tardioris ingenii) Gepidów.

Powyższa etymologia i znaczenie nazwy plemienia mogą zastanawiać. Jest bowiem pewne, że określenia tego używali także sami Gepidowie $^{52}$, a trudno wyobrazić sobie, by korzystali z określenia obraźliwego i nadanego przez nieprzyjaciół. W tym kontekście interesu-

47 Por. Iordanes, Getica 94.

48 Por. Słownik łacińsko-polski, t. 4, red. M. Plezia, Warszawa 1999, s. 160 (hasło piger, -gra, -grum).

49 Nie ma germańskiego słowa gapa, gepan, gipas, które by oznaczało 'gnuśny, ospały'. Por. Zwolski, Kasjodor i Jordanes, s. 150.

50 Por. Iordanes, Getica 95.

51 Por. Iordanes, Getica 100.

52 To najprawdopodobniej gepidzkie otoczenie króla Thrasaryka ufundowało wspomniane epitafium z meczetu Vefa kilise camii. 
jąca jest hipoteza Rolanda Steinachera, który zastanawia się nad możliwością przyjęcia jako pierwotnej formy *Gibidoz, co oznaczać może zarówno obdarzonych (błogosławionych) przez Boga, jak i szczodrych czy hojnych. Zdaniem badacza przy jak najbardziej możliwej zmianie w wymowie $b$ na $p$ nazwa plemienia będzie dla Gota wskazywała właśnie na te cechy, które przypisywali Gepidom Goci, co korzystając z plemiennego ustnego przekazu, utrwalił w tradycji literackiej Jordanes, czyli ludzi ospałych, nieaktywnych, leniwych, fizycznie i psychicznie ociężałych $^{53}$.

W pierwszej połowie VI wieku Izydor z Sewilli podaje inną etymologię nazwy plemienia Gepidów, wywodząc ją od łacińskiego słowa pedes ('nogi') i stwierdzając, że zwykli oni podejmować walkę pieszo raczej niż konno i stąd wywodzi się ich nazwa ${ }^{54}$. Marc Reydellet określa tę etymologię jako zlatynizowaną i życzliwą wersję przekazu Jordanesa ${ }^{55}$. Istotnie wydaje się, że wspominana przez Jordanesa powolność Gepidów, która miała ich charakteryzować nie tylko w czasie morskiej podróży, może być połączona z ich powolną (bo pieszą) walką.

\section{Podsumowanie}

Jak widać, obraz Gepidów przekazany przez źródła jest rzeczywistością złożoną i wieloaspektową. Odzwierciedla on ich historię i dostarcza informacji o niektórych cechach ich tożsamości, ale - co ważne - ukazuje przemiany postrzegania i oceny. Różne elementy obrazu plemienia pojawiają się w okresach rozsianych przez całą historię ich aktywności. Były one też obecne, a nawet się rozwijały i ubogacały jeszcze na długo

53 Por. Steinacher, Rom und die Barbaren, s. 56-57.

54 "Gipedes pedestri proelio magis quam equestre sunt usi, ex hac causa vocati”. Isidorus Hispalensis, Etymologiae 9, 2, 92.

55 Por. komentarz M. Reydelleta w: Isidore de Séville, Étymologies. Livre IX. Les langues et les groupes sociaux, Paris 1984, s. 92. 
po upadku państwa Gepidów, gdy zniknęli oni ze sceny politycznej i społecznej, ale przetrwała pamięć o nich. Wskazane w powyższym artykule cechy z pewnością nie wyczerpują tematu, który może być rozwijany także w dłuższych i bardziej szczegółowych opracowaniach. Może też posłużyć jako materiał do badań porównawczych obrazu dotyczących innych plemion. Należy zauważyć, że wykorzystane źródła przedstawiają ocenę z zewnątrz (przez pisarzy rzymskich, bizantyjskich oraz tradycję gocką), sformułowaną niekiedy z dłużej perspektywy czasowej. Już jednak to sumaryczne zestawienie ukazuje, że w postrzeganiu i przedstawieniu „,innego”, „obcego”, „barbarzyńcy” ma znaczenie wiele czynników. Są w nich zawarte obiektywne i potwierdzone w źródłach informacje, ale pojawiają się też elementy legendarne, często interesujące i barwne, ale niekoniecznie mające podstawy w rzeczywistości. Gepidowie nie otrzymali w starożytności swej historii plemiennej, jednak opisy zawarte w źródłach przedstawiają ich obraz z pewnością interesujący i charakterystyczny.

\section{The Formation of the Image of the Gepids in the Ancient and Early Medieval (3rd-7th c.) Sources}

(summary)

The aim of the article is to present the dynamics of the development of the image of the Gepid tribe in ancient and early medieval sources. Roman and Byzantine sources from the period of between the 3rd and 7th c. have been used in the analysis. The topic was handled in points discussing the three basic elements of their perception and presentation: the features related to their manner of fighting (bravery, cruelty and using a sword as specific combat tactics); the kinship of the Gepids and of the Goths; the heaviness of their character, the slowness of movements and an infantry style of fighting (as opposed to the horse fighting of the other peoples). The article presents both the above-mentioned basic elements of the image of the tribe, as well as the changes in its perception and the development of this image, which has gradually gained new elements derived from various traditions.

Keywords: Gepids; Barbarians; Jordanes; Procopius 


\title{
Kształtowanie się obrazu Gepidów w źródłach antycznych i wczesnośredniowiecznych (III-VII wieku)
}

\author{
(streszczenie)
}

Celem artykułu jest prezentacja dynamiki rozwoju obrazu plemienia Gepidów w źródłach antycznych i wczesnośredniowiecznych. W analizie zostały wykorzystane źródła rzymskie i bizantyjskie z okresu III-VII wieku. Temat został zrealizowany w punktach omawiających trzy zasadnicze elementy ich postrzegania i prezentacji: cechy związane z prowadzonymi walkami (waleczność, okrucieństwo oraz posługiwanie się mieczem jako szczególna taktyka walki); pokrewieństwo Gepidów z Gotami; ociężałość ich charakteru, powolność ruchów i pieszy styl walki (w odróżnieniu od walki konnej innych ludów). Artykuł przedstawia zarówno wymienione zasadnicze elementy obrazu plemienia, jak i przemiany jego postrzegania oraz rozwój obrazu, który stopniowo wzbogacał się o nowe elementy czerpane $\mathrm{z}$ różnych tradycji.

Słowa kluczowe: Gepidowie; barbarzyńcy; Jordanes; Prokopiusz z Cezarei

\section{Bibliografia \\ Źródla}

Cassiodorus Senator, Variarum libri XII, tł. A. Kołtunowska - R. Sawa, Synody i kolekcje praw, t. 11, Kraków 2017.

Chronicon paschale, t. 1-2, ed. L. Dindorf, CSHB, Bonn 1832.

Ennodius, Panegyricus dictus clementissimo regi Theoderico, w: Magno Felice Ennodio, Panegirico del clementissimo re Teoderico (opusc. 1), ed. S. Rota, Roma 2002, s. $189-230$.

Etymologicon magnum seu magnum grammaticae penu, ed. F. Sylburg, Lipsiae 1866.

Hieronymus, Epistulae, tł. J. Czuj, Hieronim ze Strydonu, Listy IV (116-130), opr. H. Pietras, ŹMT 63, Kraków 2011.

Histoire Auguste, t. 5/2-3, ed. F. Paschoud, Paris 2002-2011.

Ioannes Malalas, Chronographia, ed. L. Dindorf, CSHB, Bonn 1821.

Iordanes, Getica, w: Iordanis Romana et Getica, ed. Th. Mommsen, MGH AA 5, 1, Berolini 1882, s. 53-138, tł. E. Zwolski, Jordanes, O pochodzeniu i czynach Gotów, w: E. Zwolski, Kasjodor i Jordanes. Historia gocka czyli scytyjska Europa, Lublin 1984, s. 89-146.

Iordanes, Romana, w: Iordanis Romana et Getica, ed. Th. Mommsen, MGH AA 5, 1, Berolini 1882, s. 1-52. 
Isidorus Hispalensis, Etymologiae, w: Isidore de Séville, Étymologies Livre IX. Les langues et les groupes sociaux, éd. M. Reydellet, Paris 1984.

Panegyricus III (11). Eiusdem magistri Mamertini genethliacus Maximiani Augusti (Treviri 291 d.C.), w: Panegirici Latini, ed. D. Lassandro - G. Micunco, Torino 2013, s. 78-99.

Panegyricus IV (8). Incerti Panegyricus dictus Constantino Caesari (Treviri 297 d.C.), w: Panegirici Latini, ed. D. Lassandro - G. Micunco, Torino 2013, s. 100-124.

Procopius Caesariensis, De bellis, w: Procopius, History of the Wars, t. 1-5, ed. H.B. Dewing, LCL, Cambridge 1961-1962, tł. D. Brodka, Prokopiusz z Cezarei, Historia wojen, t. 1-2, Kraków 2013-2015.

Salvianus Massiliensis, De gubernatione Dei, w: Salvien de Marseille, Oeuvres, t. 2, ed. G. Lagarrigue, SCh 220, Paris 1975.

Sidonius Apollinaris, Carmina, w: Sidoine Apollinaire, t. 1, ed. A. Loyen, Paris 2003.

Zosimus, Historia Nova, ed. L. Mendelssohn, BT, Lipsiae 1887.

\section{Opracowania}

Barbero A., Barbari. Imigrati, profughi, importati nell'Impero romano, Bari 2006.

Brodka D., Die Wanderung der Hunnen, Vandalen, West- und Ostgoten - Prokopios von Kaisereia und seine Quellen, „Millennium. Jahrbuch zu Kultur und Geschichte des ersten Jahrtausends n. Chr." 10 (2013) s. 13-38.

Bystrický P., Longobardsko-gepidské nepriatel'stvov case Justiniánovej vojny proti Gótom, „Byzantinoslovaca” 6 (2017) s. 31-47.

Çetinkaya H., An Epitaph of a Gepid King at Vefa Kilise Camii in Istanbul, REB 67 (2009) s. 225-229.

Demougeot E., La formation de l'Europe et les invasions Barbares. Des origines germaniques à l'avènement de Dioclétien, Paris 1969.

Goffart W., Barbarian Tides. The Migration Age and the Later Roman Empire, Philadelphia 2006.

Goffart W., Rome's Fall and After, London - Ronceverte 1989.

Harper K., The Fate of Rome. Climate, Disease, and the End of an Empire, Princeton 2017. 
Kiss A.P., Gepiden im heutigen Bulgarien?, „Studia Hungaro-Bulgarica. Sumen-Szeged" 3 (2014) s. 19-34.

Lippold A., Historia Augusta, w: RAC 15, 687-723.

Magomedov B., Gepids in the 3rd-5th centuries AD, „Ancient West \& East” 2/1 (2003) s. $146-156$.

Mathisen R.W., Violent Behavior and the Construction of Barbarian Identity in Late Antiquity, w: Violence in Late Antiquity. Perceptions and Practices, ed. H.A. Drake, London - New York 2016, s. 27-35.

Pandura M., „, Ardarici gladius”. Historia Królestwa Gepidów (454-567), „Slavia Antiqua" 45 (2004) s. 55-88.

Pandura M., Origo Gepidarum, w: Origines mundi, gentium et civitatum, red. S. Rosik - P. Wiszewski, Wrocław 2001, s. 96-102.

Paschoud F., Commentaire de la Vita Probi, w: Histoire Auguste, t. 5/2, ed. F. Paschoud, Paris 2002, s. 43-168.

Paschoud F., Commentaire de la Vita Claudii, w: Histoire Auguste, t. IV/3, ed. F. Paschoud, Paris 2011, s. 243-342.

Pohl W., Die Gepiden und die Gentes an der mittleren Donau nach dem Zerfall des Attilareiches, w: Die Völker an der mittleren und unteren Donau im fünften und sechsten Jahrhundert, red. H. Wolfram - F. Daim, Wien 1980, s. 240-272.

Pohl W., Telling the Difference. Signs of Ethnic Identity, w: From Roman Provinces to Medieval Kingdoms, ed. T.F.X. Noble, New York 2006, s. 120-167.

Prostko-Prostyński J., Adolf Lippold. Historia Augusta, Reallexikon für Antike und Christentum, 15, 1990, coll. 689-723, „Studia Źródłoznawcze” 36 (1997) s. 131-132.

Rácz Z. - Vida T., Germánok keletröl és nyugatról: A gepidák és langobardok régészete - Germanen von Osten und Westen: Die Archäologie der Gepiden und Langobarden, w: 7000 év története: Fejezetek Magyarország régészetéből - 7000 Jahre Geschichte: Einblicke in die Archäologie Ungarns, ed. O. Heinrich-Tamáska D. Winger, Remshalden 2018, s. 189-210.

Rota S., Commento, w: Magno Felice Ennodio, Panegirico del clementissimo re Teoderico (opusc. 1), ed. S. Rota, Roma 2002, s. 231-428 (wydanie bilingwiczne).

Sarantis A., War and Diplomacy in Pannonia and the Northwest Balkans during the Reign of Justinian. The Gepid Threat and Imperial Responses, DOP 63 (2009) s. $15-40$. 
Słownik łacińsko-polski, t. 4, red. M. Plezia, Warszawa 1999.

Wilczyński M., Exercitus barbarorum. Organizacja i działania wojsk ludów germańskich osiadtych $w$ V i VI wieku w basenie Morza Śródziemnego, VoxP 63 (2015) s. 287-305.

Wolfram H., Storia dei Goti, Roma 1985. 